\title{
ASSESSMENT OF CARBACETAM EFFECT WITH CEREBRAL MITOCHONDRIAL DYSFUNCTION OF RATS WITH TYPE 2 DIABETES MELLITUS*
}

\author{
O. G. Kmet, N. D. Filipets, Yu. Ye. Rohovyi, \\ T. I. Hrachova, Y. M. Vepriuk, K. V. Vlasova \\ Higher State Educational Establishment of Ukraine "Bukovinian State Medical University", \\ Chernivtsi, Ukraine \\ kmet.olga@bsmu.edu.ua
}

Nowadays the fact that diabetes mellitus (DM) has acquired signs of noninfectious epidemic and become an independent risk factor of cerebral pathology is universally recognized. In addition to vascular damage caused by DM direct disorder of carbohydrate metabolism in the brain occurs. Excessive glucose concentration causes a toxic effect due to an increased amount of glycolysis products, lipid and protein peroxide oxidation, decreased membranous potential of the mitochondria and deficiency of neuron energy supply due to mitochondrial dysfunction. Chronic hyperglycemia, in particular, results in activation of polyol way of glucose metabolism in the brain causing exhaustion of NADPH-oxidase reserve [1]. Appropriate correlation of oxidative and reduced forms of nicotinamide coenzymes is essential for an effective functioning of electron transport chain of the mitochondria. Inequality of this correlation leads to imbalance of the energy biotransformation system [2]. The totality of the above factors not only potentiate diabetic damage of the central nervous system (CNS), but an early onset and more severe development of neurodegenerative processes as well, which is more specific for type $2 \mathrm{DM}$.

Glucose is the main source of energy for the brain. However, limited glycolytic ability makes neurons strongly dependent on mitochondrial respiration - the main ATP generator to perform various cellular functions [3, 4]. Due to importance of mitochondrial energy supply defects of mitochondrial functioning are reflected on the cellular and systemic levels. At the same time, the brain containing the largest amount of mitochondria is a regulation center of the body energy homeostasis. Thus, correction of

* The work was performed in accordance with the planned research of the department of Pathological Physiology of the Higher State Educational Establishment of Ukraine «Bukovinian State Medical University» on the topic: «New methodical approaches to the pathogenetic treatment of dysfunction of the proximal nephron in conditions of the development of dysregulation pathological process of renal and non-renal origin» (state registration number 0118U001193).

The Ministry of Health of Ukraine is the institution that finances the research.

The authors assume responsibility for the published work.

The authors guarantee absence of competing interests and their own financial interest when carrying out the research and writing the article.

The manuscript was received by the editorial staff 28.02.2020. 
mitochondrial dysfunction of the brain and decrease of energy deficiency is a topical area of pharmacological protection.

According to the latest scientific data mitochondria contain gamma-aminobutyric acid (GABA) - an inhibitor neurotransmitter of the CNS and trophic factor of synaptogenesis. It functional cycle is closely associated with glucose metabolism. Considering cerebroprotective effect of GABA agents in case of functional- organic disorders of the CNS, the issue concerning carbacetam effect, a new modulator of GABA-ergic system, is of a certain interest [5], under conditions of functional disorders of the cerebral mitochondria state caused by type 2 DM.

Objective of the study: experimental investigation of carbacetam effect with cerebral mitochondrial dysfunction of rats with type 2 diabetes mellitus.

\section{MATERIALS AND METHODS}

The experiments were conducted on laboratory nonlinear albino male rats with the body weight $0.18-0.20 \mathrm{~kg}$, kept under standard vivarium conditions with natural day and night changes.

All the manipulations were conducted according to the Requirements of the European Convention for the Protection of Vertebrate Animals Used for Experimental and other Scientific Purposes (18.03.1986), the European Council Directive № 609, dated 24.11.1986, and the Order of the Ministry of Health of Ukraine № 690, dated 23.09.2009.

Type $2 \mathrm{DM}$ was simulated by streptozotocin (Stz) in the dose of $30 \mathrm{mg} / \mathrm{kg}$ on the citrate buffer $(\mathrm{pH}=4.5)$ injected through the peritoneum of rats kept during 30 days on a high-fat diet with a free access to fructose solution $(200 \mathrm{~g} / \mathrm{L})$ [6]. On the $11^{\text {th }}$ week after Stz injection the group of rats with DM (7 rats) received a course (14 days) of carbacetam injections through the peritoneum in the dose of $5 \mathrm{mg} / \mathrm{kg}$ in the volume $1 \mathrm{ml}$ of $0,9 \% \mathrm{NaCl}$ solution $/ 0.1 \mathrm{~kg}$ of the body weight. The groups of comparison, that is, control group and the group of rats with simulated pathology (7 rats in each) received a solvent through the peritoneum in the similar regimen.

Euthanasia of rats was conducted under light ether narcosis. The brain was removed cold and washed thoroughly with cool $0.9 \%$ $\mathrm{NaCl}$ solution. The hippocampus and the cerebral cortex were isolated according to the stereotaxic atlas [7].

Mitochondrial fraction of homogenates of the structures examined was isolated by means of the differentiation centrifugation method in homogenization medium: sucrose $250 \mathrm{mM}$, ethylene diamine tetraacetate (EDTA) $1 \mathrm{mM}$, tris- $\mathrm{HCl} 10 \mathrm{mM}, \mathrm{pH} 7.4$ at a temperature of $0-3^{\circ} \mathrm{C}[8]$.

The intensity of lipid peroxide oxidation (LPO) in the mitochondria was assessed by the levels of active products reacting with 2-thiobarbituric acid (TBA AP) [9]; carbonylation level of mitochondrial proteins was assessed by the use of 2.4-dinitrophenylhydrazone with formation of carboxylphenylhydrazone (CPH) [10]. The state of the antioxidant protection system in the mitochondria was assessed by the activity of superoxide dismutase (SOD) enzymes [EC 1.15.1.1] and catalase [EC 1.11.1.6] [11]. The activity of enzymes of a-ketoglutarate dehydrogenase ( $\alpha-\mathrm{KGDH})$ [EC 1.2.4.2] and succinate dehydrogenase (SDH) [EC 1.3.5.1] was determined by means of spectrophotometric method [12].

Opening of the mitochondrial pore was examined by means of spectrophotometric registration of mitochondrial swelling and changes of the suspension optic density at $\lambda=520$ during 60 minutes. A relative rate of mitochondrial swelling was determined as difference between the organelle swelling rate at the $60^{\text {th }}$ minute of swelling with the presence of inductor $\mathrm{Ca}^{2+}(50 \mathrm{mcmol} / \mathrm{L})$ was registered $[13,14]$. Protein concentration in the incubation medium was determined by means of Lowry method; it was $0.4 \mathrm{mg} / \mathrm{ml}$ [15].

The results of the study were statistically processed by means of t-Student parametric criterion. In case normal distribution was absent, Mann-Whitney U-criterion was used. Differences were considered statistically valuable with $\mathrm{p} \leq 0.05$.

Point estimate of the results was presented in the form of mean values and standard mean error $(\mathrm{M} \pm \mathrm{m})$. 


\section{RESULTS AND THEIR DISCUSSION}

The development of DM was confirmed by the glucose level obtained in rats at week 10 after administration of Stz, which was $11,99 \pm 1.562 \mathrm{mmol} / \mathrm{L}$, against $4.87 \pm 0.713$ $\mathrm{mmol} / \mathrm{L}$ in control $(\mathrm{p}<0.05)$. Compared with the non-correction group, no changes in glycemia were detected on day 14 of carbacetam administration $(9.94 \pm 0.932 \mathrm{mmol} / \mathrm{L})$.

The results of the conducted studies demonstrated that TBA AP content increased in the mitochondria of the examined cerebral structures of rats with type 2 DM (Fig. 1). Thus, in comparison with the control group TBA AP content in the cerebral cortex and hippocampus $82.3 \%$ and $106.1 \%$ increased respectively. The obtained result correlates with the conclusions drawn by other scientists who stated that TBA AP content increased due to the effect of highly reactive oxygen forms acting on polyunsaturated fatty acids, components of phospholipids of all the cellular membranes; therefore, this parameter is a marker of mitochondrial membrane damage [16].

At the same time, in rats with type $2 \mathrm{DM}$ carboxylphenylhydrazone content in the cerebral cortex was $37.7 \%$ higher than that in the control group, and $43.2 \%$ higher - in the hippocampus.
After administration of carbacetam during 14 days to rats with type 2 DM TBA AP content in the cerebral cortex $20.9 \%$ decreased, and in the hippocampus $-40.2 \%$ respectively (Fig. 1). CPH content in the cerebral cortex and hippocampus $20.9 \%$ and $25.6 \%$ decreased respectively.

One of the important enzymes of the antioxidant system is SOD catalyzing dismutation reaction of superoxide anion-radicals and transforming them into less reactive-able molecules of hydrogen peroxide. SOD activity in the mitochondria of rats with DM $23.3 \%$ decreased in the cerebral cortex. This parameter was characterized by a tendency to decrease in the hippocampus in comparison with the control group (Table). After carbacetam administration during 14 days SOD activity in both structures of the brain increased; and the parameters did not differ reliably from that of the control.

Considering the fact that hydrogen peroxide, resulted from dismutation of superoxide radical, is carried out by catalase-peroxidase systems, therefore the next step in our study was to study the activity of catalase in MTX GM (Table). In rats with type $2 \mathrm{DM}$ catalase activity $29.4 \%$ and $51.5 \%$ decreased in the cerebral cortex and hippocampus respectively as

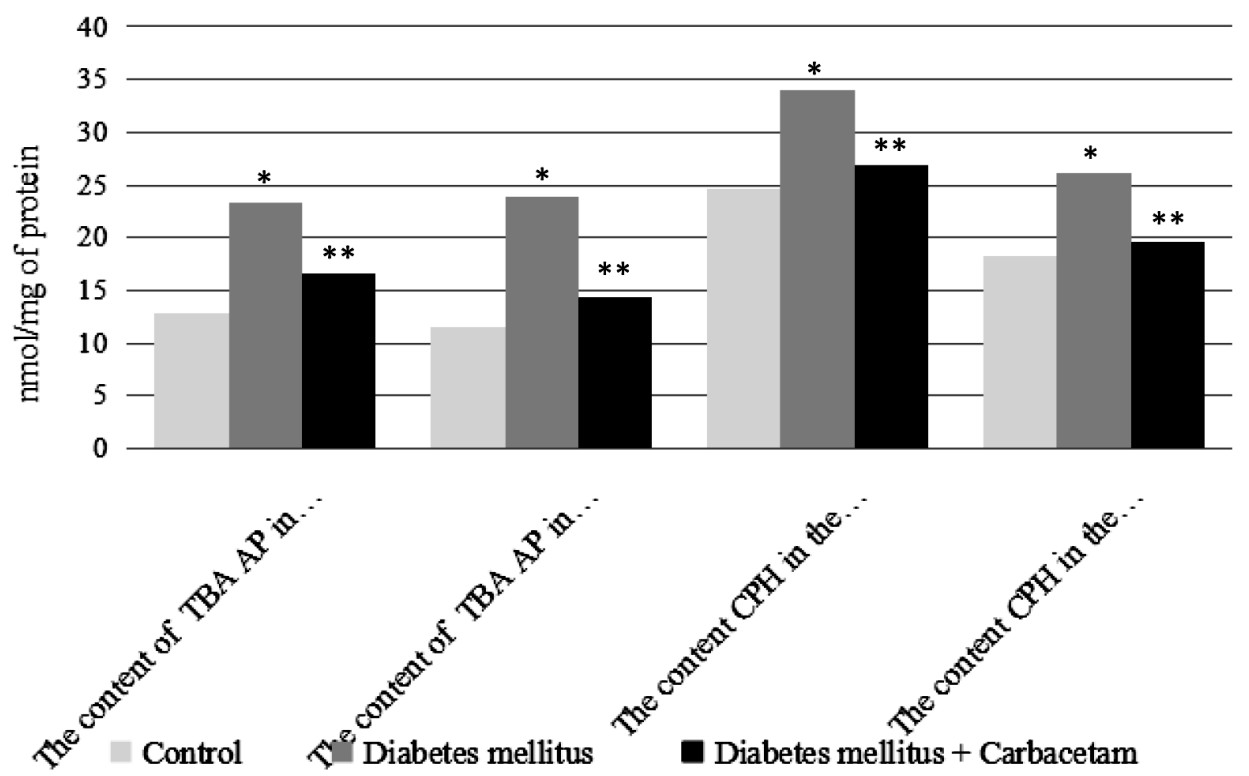

Fig.1. Carbacetam effect on free radical lipid and protein oxidation in the mitochondrial fraction of the cerebral cortex and hippocampus of rats with type 2 diabetes mellitus

Notes:

* reliability of difference compared with the control group of rats,

** reliability of difference compared with the group of rats with type 2 diabetes mellitus. 
Carbacetam effect on the state of antioxidant protection in the mitochondrial fraction of the cerebral cortex and hippocampus of rats with type 2 diabetes mellitus $(M \pm m, n=7)$

\begin{tabular}{c|c|c|c|c}
\hline Indices & $\begin{array}{c}\text { Examined } \\
\text { structures } \\
\text { cerebral }\end{array}$ & Control & $\begin{array}{c}\text { Diabetes } \\
\text { mellitus }\end{array}$ & $\begin{array}{c}\text { Diabetes } \\
\text { mellitus }+ \\
\text { Carbacetam }\end{array}$ \\
\hline \multirow{2}{*}{$\begin{array}{c}\text { SOD, } \\
\text { units / mg of protein }\end{array}$} & cortex & $0,43 \pm 0,027$ & $0,33 \pm 0,017^{*}$ & $0,39 \pm 0,022$ \\
\cline { 2 - 5 } $\begin{array}{c}\text { Catalase, } \\
\text { hippocampus }\end{array}$ & $0,38 \pm 0,045$ & $0,26 \pm 0,038$ & $0,32 \pm 0,039$ \\
\hline momol H $\mathrm{O}_{2} /$ min of mg of protein & cortex & $175,9 \pm 10,58$ & $124,2 \pm 11,72^{*}$ & $187,2 \pm 19,06^{* *}$ \\
\cline { 2 - 5 } $\begin{array}{c}\text { The activity of a-KGDH, } \\
\text { nmol / min of mg of protein }\end{array}$ & hippocampus & $170,2 \pm 10,99$ & $82,5 \pm 11,28^{*}$ & $136,1 \pm 17,85$ \\
\cline { 2 - 5 } & cortex & $40,4 \pm 2,23$ & $26,5 \pm 1,01^{*}$ & $30,8 \pm 2,01^{*}$ \\
\hline $\begin{array}{c}\text { The activity of SDH } \\
\text { nmol / min of mg of protein }\end{array}$ & cortex & $6,5 \pm 0,57$ & $2,2 \pm 0,15^{*}$ & $3,5 \pm 0,23^{* * *}$ \\
\cline { 2 - 5 } & hippocampus & $7,2 \pm 0,32$ & $2,4 \pm 0,27^{*}$ & $4,5 \pm 0,19 * * *$ \\
\hline
\end{tabular}

Notes:

* reliability of difference compared with the control group of rats,

** reliability of difference compared with the group of rats with type 2 diabetes mellitus.

compared to the control indices. Due to carbacetam effect catalase activity in the cerebral cortex $50.7 \%$ increased, but in the hippocampus only a tendency to increase was observed.

Oxidative stress with hyperglycemia is known to promote excessive production of oxygen reactive forms, exhaustion of the antioxidant protection system and energy deficiency, eventually resulting in damage and death of neurons. Therefore, we examined the activities of Krebs cycle dehydrogenases - a-KGDH and SDH, which determine efficacy of energy supply in the mitochondria. Under conditions of type 2 DM development a-KGDH activity was found $34.4 \%$ decreased in the cerebral cortex, and $38.4 \%$ decreased - in the hippocampus; SDH activity in both examined structures $66.4 \%$ decreased on an average.

After carbacetam administration, activity of both enzymes increased. Though, a-KGDH activity was $35.1 \%$ higher in the hippocampus only; SDH activity was $59.1 \%$ higher in the cerebral cortex and $87.5 \%$ - in the hippocampus, compared with pathology group.

To characterize structural-functional state of the mitochondria, organelle swelling was examined by the dynamics of light dispersion intensity of mitochondrial suspension during 60 minutes of incubation. The parameters were considered (units/mg of protein) on the $5^{\text {th }}$ and $60^{\text {th }}$ minutes of observation (initial and final periods of observation respectively). Thus, the level of light dispersion in the mitochondrial suspension of the brain in the control group of rats decreased from $0.908 \pm 0.016$ to $0.839 \pm 0.014$ (Fig. 2). It is indicative of an important physiological role of mitochondria in maintenance of their own homeostasis due to their ability to accumulate and retain $\mathrm{Ca}^{2+}$ ions in the matrix.

Under conditions of type $2 \mathrm{DM}$ light dispersion in the mitochondrial suspension decreased from $0.646 \pm 0.015$ to $0.525 \pm 0.009$. It should be noted, that parameters of the initial and final periods of observation in rats with $\mathrm{DM}$ were lower than that of the control, which is indicative of possible damage of the mitochondrial internal membrane resulting in disorders of energy function [17].

After carbacetam administration the level of light dispersion decreased from $0.887 \pm 0.013$ to $0.837 \pm 0.012$. At the same time, the data obtained appeared to be higher than the parameters of rats with simulated pathology. Therefore, it is indicative of carbacetam ability to decrease excessive opening of the mitochondrial pore.

Further studies demonstrated (Fig. 3) that dynamics of light dispersion intensity in the mitochondrial suspension was similar to changes occurring in the cerebral cortex. Though, in rats with DM more pronounced damage of mi- 


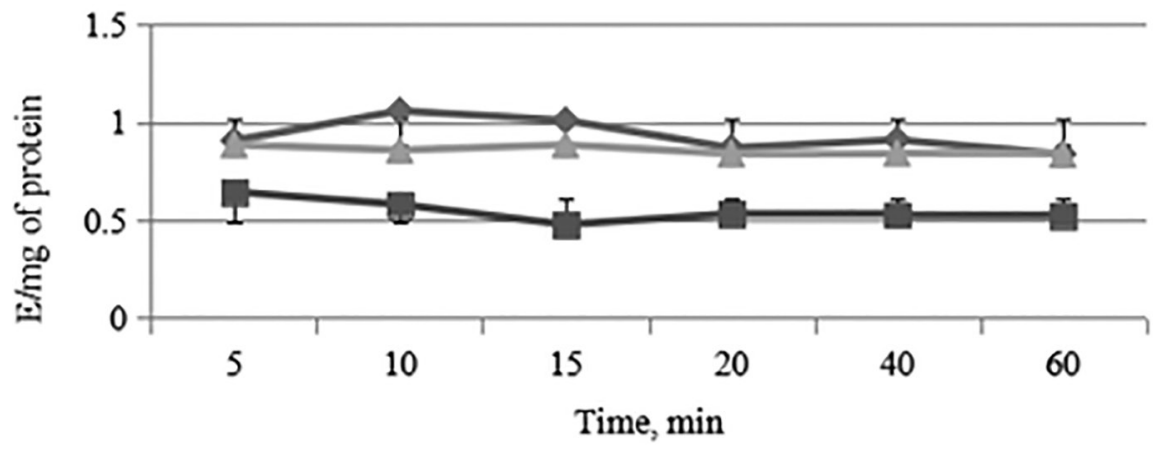

$\leadsto$ Control $\rightarrow-$ Diabetes mellitus $\rightarrow$ Diabetes mellitus + Carbacetam

Fig. 2. Intensity of mitochondrial swelling in the cerebral cortex of rats with type 2 diabetes mellitus after carbacetam administration during 14 days in the dose of $5 \mathrm{mg} / \mathrm{kg}$.

The results are represented as $\mathrm{Me}[\min -\max ], \mathrm{n}=7, \mathrm{P}<0.05$.

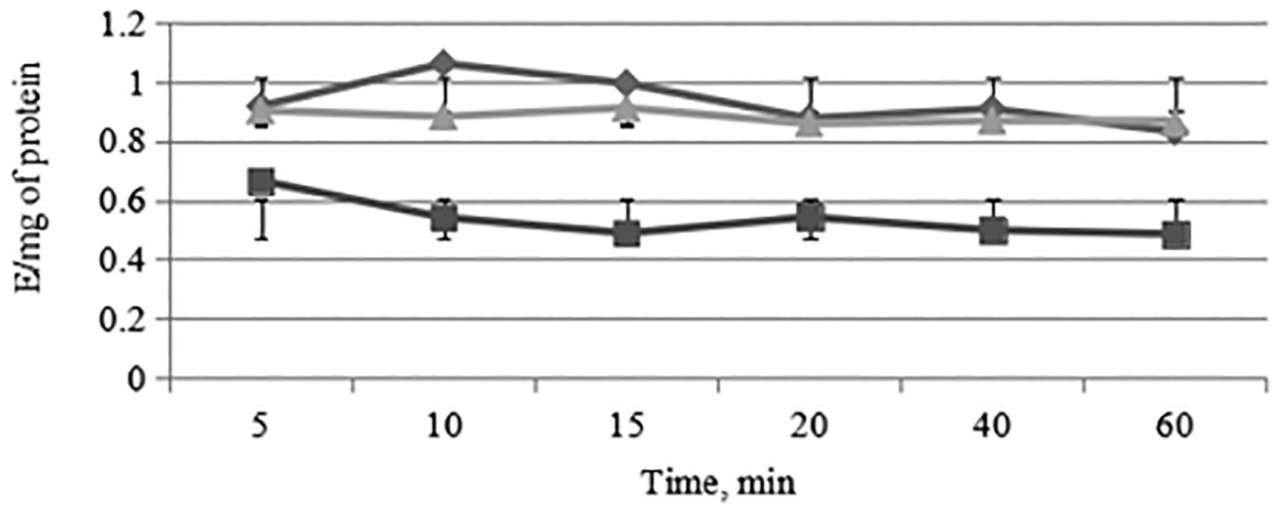

$\neg$ Control $\rightarrow$ - Diabetes mellitus $\rightarrow$ Diabetes mellitus + Carbacetam

Fig. 3. Intensity of mitochondrial swelling in the hippocampus of rats

with type 2 diabetes mellitus after carbacetam administration during 14 days in the dose of $5 \mathrm{mg} / \mathrm{kg}$.

The results are represented as $\mathrm{Me}[\min -\max ], \mathrm{n}=7, \mathrm{P}<0.05$.

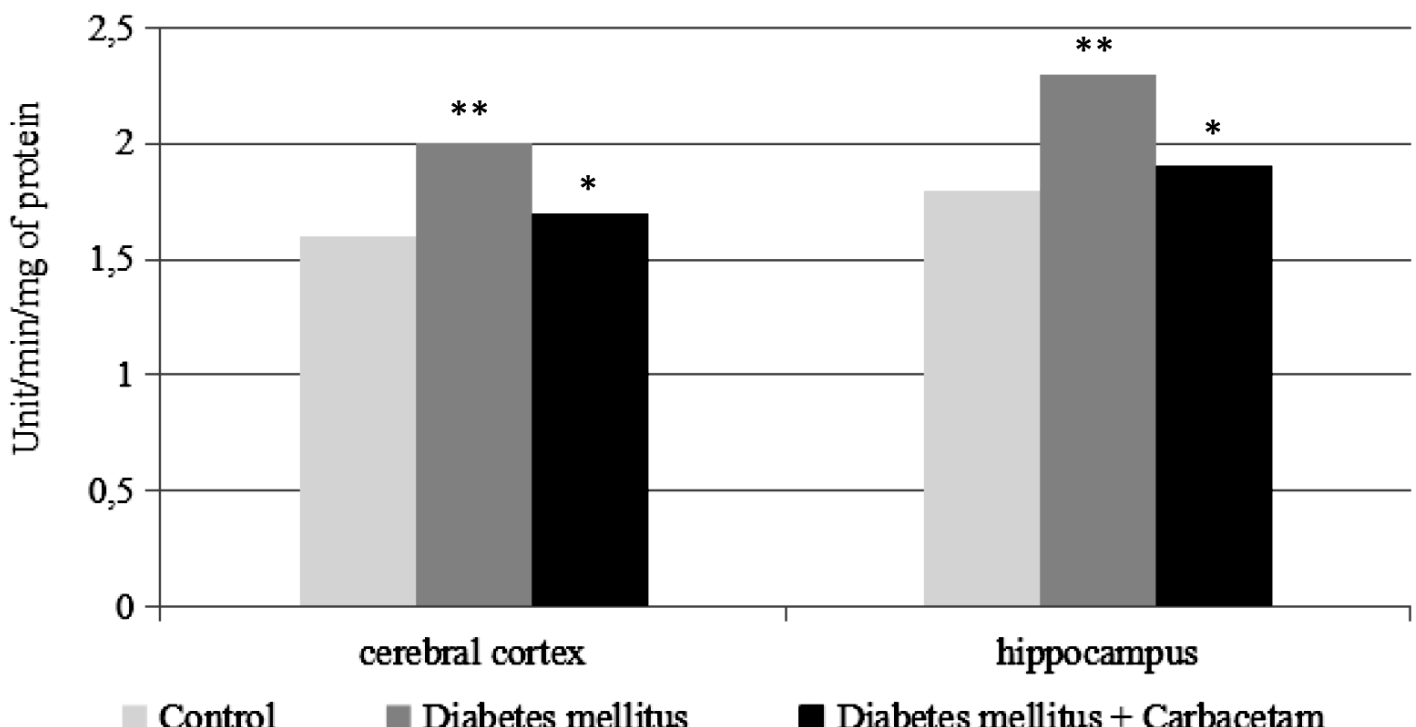

Fig. 4. Relative rate of mitochondrial swelling in the cerebral cortex of rats with type 2 diabetes mellitus after carbacetam administration during 14 days in the dose of $5 \mathrm{mg} / \mathrm{kg}(\mathrm{M} \pm \mathrm{M}, \mathrm{n}=7)$.

Notes:

* reliability of difference compared with the control group of rats,

** reliability of difference compared with the group of rats with type 2 diabetes mellitus. 
tochondria is found in this structure, which is indicative of its higher sensitivity under our conditions of the experiment.

Calculations demonstrated that a relative rate of mitochondrial swelling in rats with $\mathrm{DM}$ in comparison with the control group $25.0 \%$ increased in the cerebral cortex and $27.8 \%-$ in the hippocampus (Fig. 4). After carbacetam use a relative rate of mitochondrial swelling decreased in comparison with the control group of rats in both structures examined: $15.0 \%$ in the cerebral cortex and $17.4 \%$-in the hippocampus.

Thus, our experimental studies established that disorders of the prooxidant-antioxidant balance and energy supply of neurons occurred in the mitochondria of the cerebral cortex and hippocampus of rats with type $2 \mathrm{DM}$, and their functional state was disturbed. The obtained results correlate with the data suggested by other scientists and evidence that mitochondrial dysfunction is a valuable pathologic base of neurodegenerative disorders in the CNS [18, 19]. Carbacetam decreases AP TBA and CPH content, increases activity of antioxidant enzymes and improves parameters of energy metabolism in the mitochondria, and therefore, decreases loss of functioning neurons specific for type 2 DM. A trigger mechanism of carbacetam action is a well-balanced effect on the GABA system in the CNS including the cerebral vessels [20], which is reflected by improvement of cerebral circulation peculiar for GABA modulators. Increase of the blood flow volume and oxygen content in the cerebral cells promotes reduced production of oxygen active forms and harmful effects of AP TBA and CPH respectively. Increased activity of SOD and catalase enables to suggest carbacetam antioxidant effect.

One more important peculiarity of carbacetam is increased activity of Krebs cycle en- zymes - $a-\mathrm{KGDH}$ and SDH in the mitochondria, which is indicative of improvement of energy metabolism in the examined neuron organelles of the cerebral cortex and hippocampus damaged with neurodegeneration including that one occurring with DM. The above processes cause an improvement of the mitochondrial functional state which is evidenced by the dynamics of light dispersion in the mitochondrial suspension which is indicative of reduced mitochondrial pore under carbacetam effect. The main mechanism of carbacetam action might be associated with prevailing intensification of NAD-dependent oxidation, which is one of the ways to increase resistance of the mitochondrial respiratory chain. Moreover, carbacetam is not excluded to modulate $\mathrm{Ca}^{2+}$ and $\mathrm{K}^{+}$currents. Activation of mitochondrial ATP-dependent potassium channels is known to result in decrease of $\mathrm{Ca}^{2+}$ load and inhibition of an excessive opening of the mitochondrial pore [21].

Considering the scientific data concerning participation of a polyol way of glucose metabolism in the mechanisms of CNS dysfunction, we can suggest inhibiting carbacetam effect on the process. Carbacetam is not excluded to produce certain effect on GABA-receptors of the pancreas [22]. Modulation of these receptors promotes decreased sorbitol synthesis due to improved regulation of insulin secretion and reduced mediators of inflammation. The above factors promote to increase NADPH supplies as the main source of energy biotransformation in the mitochondria of neurons of the examined structures - cerebral cortex and hippocampus. In general, it improves the CNS functional state which is evidenced by our previous studies [6], where in the absence of hypoglycemic effects carbacetam improved memory, cognitive and integral rational activity of rats with experimental neurodegeneration simulated by type $2 \mathrm{DM}$.

\section{CONCLUSIONS}

1. Under conditions of central nervous system damage induced by type 2 diabetes mellitus, lipid and protein peroxide oxidation increases in the mitochondrial fraction of the cerebral cortex and hippocampus of rats; activity of superoxide dismutase, catalase, a-ketoglutarate dehydrogenase, succinate dehydrogenase decreases; a relative rate of mitochondrial swelling increases.

2. After carbacetam administration during 14 days the content of products reacting with 2 -thiobarbituric acid and protein oxidation modification decrease in the mitochondria of the brain and hippocampus of rats with 
type 2 diabetes mellitus; activity of catalase in the cerebral cortex and a-ketoglutarate dehydrogenase in the hippocampus increases, activity of succinate dehydrogenase increases in both structures examined which is indicative of its antioxidant properties.
3. Decrease of a relative rate of mitochondrial swelling in the cerebral cortex and hippocampus of rats confirms a protective effect of carbacetam under conditions of mitochondrial dysfunction.

\section{REFERENCES}

1. Yanitska L, Tykhonenko T, Guzyk M, Kuchmerovska T. Endocrinology 2017;22(3): 279-283.

2. Voloshchuk ON, Kopylchuk GP. Biomed Chem 2016; 62(2): 169-172

3. Ghazaleh Ashrafi, Timothy AR. Curr Opin Neurobiol 2017; 45: 156-161. doi: 10.1016/j.conb.2017.03.007.

4. Yin F, Sancheti H, Patil I, Cadenas E. Free Radic Biol Med. 2016; 100: 108-122. doi: 10.1016/j.freeradbiomed. 2016.04.200.

5. Ziablitsev SV, Starodubska OO. Pathologia. 2017; 1: 9599. doi: 10.14739/2310-1237. 2017.1.97502.

6. Kmet OG, Filipets ND, Kmet TI, et al. Probl Endocrine Pathol 2019; 4: 52-59. doi.org/10.21856/jPEP.2019.4.07.

7. George Paxinos, Charles Watson. The Rat Brain in Stereotaxic Coordinates. 7-th Ed. Academic Press, 2013: 472 p.

8. Kopylchuk GP, Voloshchuk OM. Animal Biol 2019; 21(3): 14-20.

9. Kushnir OYu, Yaremii IM, Shvets VI, Shvets NV. Fiziol Zhurn 2018; 64(5): 54-62. doi.org/10.15407/fz64.05.054.

10. Kopylchuk GP, Voloshchuk OM. Ukr Biochem J 2016; 88(2): 66-72. doi: http://dx.doi.org/10.15407/ubj88.02.066.

11. Feysa SV. Fiziol Zhurn 2019; 65(2): 89-96. doi: doi. org/10.15407/fz65.02.089.

12. Prohorova MI. Methods of biochemical studies (lipid and energy metabolism), Leningrad, 1982: $272 \mathrm{p}$.
13. Vadzyuk OB. Ukr Biochem $J$ 2015; 87(6): 86-94. doi. org/10.15407/ubj87.06.086.

14. Eisenhofer S, Toykos F, Hense BA, et al. BMC RES Notes 2010; 3: 67. doi: 10.1186/1756-0500-3-67.

15. Ceban E, Banov P, Galescu A, Botnari V. J Med Life 2016; 9(3): 259-262.

16. Zhukovska AS, Shysh AM, Moibenko OO. Int J Physiol Pathophysiol 2012; 4: 363-370. doi: 10.1615/IntJPhysPathophys.v3.i4.80.

17. Dubinin MV, Vedernikov AA, Khoroshavina EI, et al. Biol Membranes 2015;32(5-6): 328-337.

18. Adav SS, Park JE, Sze SK. Molecular brain 2019;12(1): 1-8. doi: 10.1186/s13041-019-0430-y.

19. Ifhar LS, Ene HM, Ben-Shachar D. Eur Neuropsychopharmacol 2019; 29(5): 577-589. doi: 10.1016/j.euroneuro.2019.03.011.

20. Trujeque-Ramos S, Castillo-Rolyn D, Galarraga E, et al. Front Neurosci 2018; 12: 345. doi.org/10.3389/fnins. 2018.00345 .

21. Laskowski M, Augustynek B, Bednarczyk P, et al. Int J Mol Sci 2019;20(21): 1-18. doi:10.3390/ijms20215323.

22. Korol SV, Jin Z, Jin Y, et al. EBio Medicine 2018;30: 273-282. doi.org/10.1016/j.ebiom.2018.03.014. 


\section{ASSESSMENT OF CARBACETAM EFFECT WITH CEREBRAL MITOCHONDRIAL DYSFUNCTION OF RATS WITH TYPE 2 DIABETES MELLITUS}

O. G. Kmet, N. D. Filipets, Yu. Ye. Rohovyi,

T. I. Hrachova, Y. M. Vepriuk, K. V. Vlasova

Higher State Educational Establishment of Ukraine "Bukovinian State Medical University", Chernivtsi, Ukraine

kmet.olga@bsmu.edu.ua

Neurodegenerative disorders in the cerebral cortex and hippocampus are one of the most common causes of disability and mortality in patients with diabetes. Excessive glucose concentration causes a toxic effect due to an increased amount of glycolysis products, lipid and protein peroxide oxidation, decreased membranous potential of the mitochondria and deficiency of neuron energy supply due to mitochondrial dysfunction. Gammaamino butyric acid is known to localize to the mitochondria, and its functional cycle is closely linked to glucose metabolism.

Objective of the study: experimental investigation of carbacetam effect with cerebral mitochondrial dysfunction of rats with type 2 diabetes mellitus.

The experiments were conducted on laboratory nonlinear albino male rats with the body weight $0.18-0.20 \mathrm{~kg}$. Type 2 diabetes is modeled on streptozotocin and a high-fat diet. Carbacetam was administered intraperitoneally at a dose of $5 \mathrm{mg} / \mathrm{kg}$, once daily for 14 days.

Under conditions of central nervous system damage induced by type 2 diabetes mellitus, lipid and protein peroxide oxidation increases in the mitochondrial fraction of the cerebral cortex and hippocampus of rats; activity of superoxide dismutase, catalase, a-ketoglutarate dehydrogenase, succinate dehydrogenase decreases; a relative rate of mitochondrial swelling increases.

After carbacetam administration during 14 days the content of products reacting with 2-thiobarbituric acid and protein oxidation modification decrease in the mitochondria of the brain and hippocampus of rats with type 2 diabetes mellitus; activity of catalase in the cerebral cortex and a-ketoglutarate dehydrogenase in the hippocampus increases, activity of succinate dehydrogenase increases in both structures examined which is indicative of its antioxidant properties.

Decrease of a relative rate of mitochondrial swelling in the cerebral cortex and hippocampus of rats confirms a protective effect of carbacetam under conditions of mitochondrial dysfunction.

Key words: carbacetam, type 2 diabetes mellitus, functional state of the mitochondria.

\section{ОЦІНКА ВПЛИВУ КАРБАЦЕТАМУ ПРИ МІТОХОНДРІАЛЬНІЙ ДИСФУНКЦІЇ ГОЛОВНОГО МОЗКУ ЩУРІВ ІЗ ЦУКРОВИМ ДІАБЕТОМ 2 ТИПУ}

Кметь О. Г., Філіпець Н. Д., Роговий Ю.є., Грачова Т. І., Вепрюк Ю. М., Власова К. В.

Вищий державний навчальний заклад Украйни "Буковинський державний медичний університет", м. Чернівиі, Україна

kmet.olga@bsmu.edu.ua

Одними з найбільш поширених причин інвалідизації та летальності хворих при діабеті є нейродегенеративні порушення у корі головного мозку та гіпокампі. Надмірна концентрація глюкози чинить токсичний вплив через зростання кількості продуктів гліколізу, пероксидного окислення ліпідів і білків, зниження мембранного потенціалу мітохондрій та дефіцит енергозабезпечення нейронів унаслідок мітохондріальної дисфрункції. Відомо, що гама-аміномасляна кислота локалізуеться у мітохондріях, її фонкціональний цикл тісно пов'язаний із метаболізмом глюкози.

Тому метою роботи було експериментальне вивчення впливу карбацетаму, модулятора ГАМКергічної системи, при мітохондріальній дисфрункції головного мозку щурів із цукровим діабетом 2 типу.

Експерименти проводили на нелінійних лабораторних білих щурах самцях масою 0,18-0,20 кг. Цукровий діабет 2 типу змодельовано стрептозотоцином і високожировою дієтою. Карбацетам вводили внутрішньоочеревинно дозою 5 мг/кг, один раз у день упродовж 14 днів.

Встановлено, що за умов індукованого цукровим діабетом 2 типу пошкодження центральної нервової системи в мітохондріальній фракції кори головного мозку та гіпокампа щурів збільшуеться пероксидне окиснення ліпідів та білків; знижуеться активність супероксиддисмутази, каталази, а-кетоглутаратдегідрогенази та сукцинатдегідрогенази; зростає відносна швидкість набухання мітохондрій.

Після введення 14 днів карбацетаму у щурів із цукровим діабетом 2 типу в мітохондріях головного мозку та гіпокампа знижуеться вміст продуктів, що реагують із 2-тіобарбітуровою кислотою та окисної модифікації білків; зростае активність каталази у корі, а-кетоглутаратдегідрогенази у гіпокампі, а сукцинатдегідрогенази - в обох досліджуваних структурах, що вказуе на його антиоксидантні властивості. 
Зниження відносної швидкості набухання мітохондрій кори головного мозку та гіпокампа щурів підтверджує протективний вплив карбацетаму за умов мітохондріальної дисфункції.

К л ючові слов а: карбацетам, цукровий діабет 2 типу, функціональний стан мітохондрій.

\section{ОЦЕНКА ВЛИЯНИЯ КАРБАЦЕТАМА ПРИ МИТОХОНДРИАЛЬНОЙ ДИСФУНКЦИИ ГОЛОВНОГО МОЗГА КРЫС С САХАРНЫМ ДИАБЕТОМ 2 ТИПА}

Кметь О. Г., Филипец Н. Д., Роговой Ю.Е., Грачева Т. И., Вепрюк Ю. М., Власова К. В.

Высшее государственное учебное заведение Украинь "Буковинский государственный медицинский университет», г. Черновиы, Украина kmet.olga@bsmu.edu.ua

Одними из самых распространенных причин инвалидизации и летальности больных при диабете является нейродегенеративные нарушения в коре головного мозга и гиппокампе. Чрезмерная концентрация глюкозы оказывает токсическое влияние из-за роста количества продуктов гликолиза, перекисного окисления липидов и белков, снижение мембранного потенциала митохондрий и дефицит энергообеспечения нейронов вследствия митохондриальной дисфункции. Известно, что гамма-аминомасляная кислота локализуется в митохондриях, ее функциональный цикл прочно связан с метаболизмом глюкозы.

Поэтому целью работы было экспериментальное изучение влияния карбацетама, модулятора ГАМК-эргической системы, при митохондриальной дисфункции головного мозга крыс с сахарным диабетом 2 типа.

Эксперименты проводили на нелинейных лабораторных белых крысах самцах массой 0,18-0,20 кг. Сахарный диабет 2 типа смоделирован стрептозотоцином и высокожировой диетой. Карбацетам вводили внутрибрюшинно в дозе 5 мг/кг, один раз в день в течение 14 дней.

Установлено, что в условиях индуцированного сахарным диабетом 2 типа повреждения центральной нервной системы в митохондриальной фракции коры головного мозга и гиппокампа крыс увеличивается перекисное окисление липидов и белков; снижается активность супероксиддисмутазы, каталазы, а-кетоглутаратдегидрогеназы и сукцинатдегидрогеназы; растет относительная скорость набухания митохондрий.

После введения 14 дней карбацетама у крыс с сахарным диабетом 2 типа в митохондриях головного мозга и гиппокампа снижается содержание продуктов, реагирующих с 2-тиобарбитуровой кислотой и окислительной модификации белков; возрастает активность каталазы в коре, a-кетоглутаратдегидрогеназы в гиппокампе, а сукцинатдегидрогеназы - в обеих исследуемых структурах, указывает на его антиоксидантные свойства.

Снижение относительной скорости набухания митохондрий коры головного мозга и гиппокампа крыс подтверждает протективное влияние карбацетама в условиях митохондриальной дисфункции.

Ключевые слова: карбацетам, сахарный диабет 2 типа, функциональное состояние митохондрий. 